\title{
Chromosome 17 Centromere Probe
}

National Cancer Institute

\section{Source}

National Cancer Institute. Chromosome 17 Centromere Probe. NCI Thesaurus. Code C122781.

A DNA probe designed for in situ hybridization. This probe is complementary to DNA sequences found in the centromeric region of chromosome 17. This probe can be used to determine gene copy number alterations. 